\title{
Muscle scars in Porcellia (Gastropoda; Pleurotomariacea) from the Carboniferous of England
}

JOHN S. PEEL

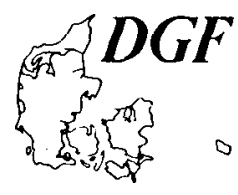

\begin{abstract}
Peel, J. S.: Muscle scars in Porcellia (Gastropoda; Pleurotomariacea) from the Carboniferous of England. Bull. geol. Soc. Denmark, vol. 35, pp. 53-58, Copenhagen, October, 29th, 1986 https://doi.org/10.37570/bgsd-1986-35-06

Two shell retractor muscles are described on an internal mould of Porcellia woodwardi, a pleurotomaria-cean gastropod from the Carboniferous of England. The scars are located at the junction between the um-bilical wall, and the apical surface and the basal surface, respectively. Similar positioning of muscle scars in Bellerophon of the same age reflects morphological convergence of the planispiral, anisostrophic Por-cellia with the planispiral, but isostrophic Bellerophon. It is concluded that the shape of muscle scars, in detail, can not contribute to solving the question of the systematic position of Bellerophon.
\end{abstract}

John S. Peel, Grønlands Geologiske Undersøgelse, Øster Voldgade 10. DK-1350 København K, Denmark, January 8th, 1986.

The bellerophontiform molluscs are a complex of more than fifty isostrophically coiled genera of uncertain systematic position. While traditionally considered to be gastropods, an extended debate exists in the literature as to whether or not this position should be maintained, or if the group should be transferred in part, or as an entity, to the Monoplacophora. The central theme in this debate concerns the presence or absence of tor- sion. Proponents of a monoplacophoran assignment consider the bellerophontiform molluscs to be untorted, with the mouth anterior and the anus posterior. In such a case, the earlier coiled portion of the shell would be located anteriorly, over the head. If bellerophontiform molluscs are considered to be gastropods, torsion necessitates that the originally posterior mantle cavity and its contained gills and anus be rotated anteriorly, to lie over the head. Thus, the earlier coiled portion of the shell would be posterior (cf. Peel 1984, text-fig. 4).

The various arguments cited in the debate are reviewed by Harper \& Rollins (1982) and need not be repeated here. It is relevant, however, to note the central position in the controversy traditionally occupied by interpretations of musculature based on preserved muscle scars. In essence, Bellerophon de Montfort 1808 was considered by Knight $(1947$; 1952) to be torted (hence, a gastropod) on the basis of parallels drawn between its single pair of circumbilical muscles and the single pair of shell-attachment muscles of some extant, slit-bearing pleurotomariaceans. Other bellerophontiform molluscs have been considered to be monoplacophorans after comparison between their multiple pairs of muscle scars and the discrete pairs of muscle scars in the living monoplacophoran Neopilina Lemche 1957, or its immediate, but ancient relatives Pilina Koken 1925 and Tryblidium Lindström 1880 (cf. Lemche \& Wingstrand 1959; Wingstrand 1985).

Muscle scars were first described in Bellerophon by Knight (1947) in specimens of Carboniferous age from North America, although somewhat similar structures were figured, apparently without comment, more than twenty years earlier in the Ordovician Sinuites ammonoides Koken 1897 by Koken \& Perner (1925, pl. 18, fig. 16). Knight (1947) also described a pair of muscle scars in an Ordovician specimen of Sinuites Koken 1896, consideming the scars to be closely comparable to those in Bellerophon. This opinion, however, is not now accepted. Only a single pair of muscle scars is present in Bellerophon, while Sinuites probably has three pairs of muscle scars in a different configuration (Peel 1980, but see also Runnegar 1981).

It is now quite widely appreciated that muscle scar patterns alone do not necessarily provide definitive evidence as to monoplacophoran or 
gastropod affinities (Harper \& Rollins 1982; Peel 1982; Runnegar 1981). The nature and location of muscle scars in Bellerophon are to a large extent the result of the isostrophic form of the shell and similarly located muscle scars occur in the isostrophic ammonites and extant Nautilus (Jordan 1968). However, a serious obstacle to the satisfactory evaluation of the significance of muscle scars in Bellerophon is the rarity of descriptions of muscle scars in relevant, undoubted, fossil gastropods, notably Palaeozoic pleurotomariaceans.

The present paper describes a single specimen of the pleurotomariacean Porcellia woodwardi (Sowerby 1829) from the Carboniferous of the United Kingdom in which muscle scars are preserved. Insofar as the imperfect preservation allows, the specimen is compared in terms of muscle scars with Bellerophon of similar age, and its contribution to the question of the systematic position of Bellerophon is evaluated.

\section{Porcelliform pleurotomariaceans}

In most pleurotomariacean gastropods, the conispiral shell is coiled into the familiar turbinate or trochoid form characteristic of gastropods in general. This basic shell form is modified during ontogeny in some members of the pleurotomariacean family Eotomariidae Wenz 1938 such that coiling becomes planispiral, i.e., lying within a single plane perpendicular to the axis of coiling. These planispiral eotomariids form a small group centred around the genus Porcellia Léveillé 1835 (Devonian-Carboniferous, ?Permian). The planispiral coiling of the porcelliform eotomariids has caused them to be assigned to the Cephalopoda (nautiloids and goniatites) and the bellerophontiform molluscs by early workers, but their assignment to the pleurotomariacean gastropods has been secure for more than a hundred years (de Koninck 1883). In the Treatise on Invertebrate Paleontology, the porcelliform pleurotomariaceans were afforded full family status as the family Porcellidae Broili 1924 (Knight et al. 1960). The close similarity between the porcelliform pleurotomariaceans and members of the family Eotomariidae was recognised by Batten (1966), who consequently abandoned the Porcellidae as a separate family.
The possibility for confusion between some porcelliform eotomariids and certain relatives of Bellerophon, e.g., Megalomphala Ulrich \& Scofield 1897, is compounded by a tendency among some of these porcelliform eotomariids to approach bilateral symmetry around the plane of coiling, i.e., to approximate the isostrophic form of the bellerophontiform molluscs. In addition, porcelliform eotomariids and many bellerophontiform molluscs possess a well-developed slit, generating a peripheral selenizone. In slit-bearing bellerophontiform molluscs, however, coiling is usually isostrophic at all stages of growth. In porcelliform eotomariids, coiling is usually clearly anisostrophic at early growth stages, even conispiral instead of planispiral. In addition, the planispiral adult often shows asymmetry about the plane of coiling, i.e., anisostrophy, in terms of whorl tumidity, the location and size of tubercles, and other details of ornamentation.

In Porcellia itself, the selenizone is at midwhorl and effectively divides the adult shell into two almost identical halves. However, examination of earlier whorls in the loosely coiled shell demonstrates a conispiral juvenile stage, permitting easy recognition of apical and umbilical surfaces. The selenizone is also at mid-whorl in $\mathrm{Ko}$ kenella Kittl 1891 (Triassic), but anistrophism is more pronounced in Talantodiscus where the selenizone also lies away from the mid-line of the whorl. Knight et al. (1960) considered Raphischisma Knight 1936 (Carboniferous) to be a close relative of Porcellia but the closed umbilicus and sub-sutural selenizone would appear to deny close affinity.

\section{Porcellia woodwardi (Sowerby 1829)}

Porcellia woodwardi differs from most species assigned to the genus Porcellia in lacking tubercles along the upper and lower surfaces of the whorl (fig. 1). In standard orientation for a conispiral gastropod, with apex upward and aperture facing the viewer, the aperture of the dextrally coiled shell lies to the right (fig. 1B). Oriented as a bellerophontiform mollusc, with the axis of coiling horizontal, the near bilateral symmetry of the whorl is evident (fig. 1D). It is equally apparent, however, that the shell merely approaches bilateral symmetry (isostrophy); minor details of whorl profile and ornamentation betray ist un- 


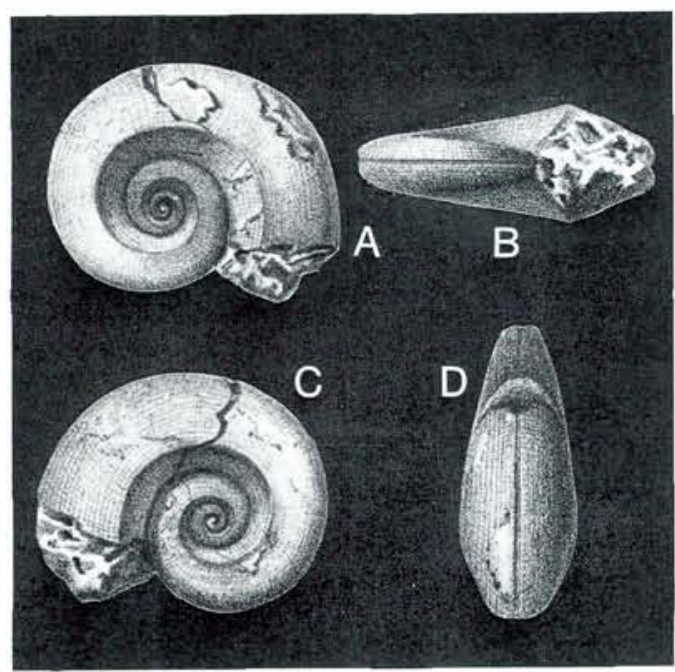

Fig. 1. Porcellia woodwardi (Sowerby 1829), line drawings reproduced from de Koninck (1883) to show general features of this Carboniferous planispiral pleurotomariacean, $\times 1$. A, upper surface (apical view); B, apertural view in standard gastropod orientation; C, basal view; D, in standard orientation for a bellerophontiform mollusc, showing the median selenizone about which the shell is almost symmetrical.

derlying anisostrophism and pleurotomariacean affinity.

The specimen with muscle scars described in the present paper is an internal mould in black limestone, preserved in the Geological Museum, Oxford, England, and collected from the Lower Carboniferous at Longnor, Staffordshire, England. The aperture is broken away and the internal mould has been excavated on the upper surface (fig. 2B). Early whorls were closed off during growth by a septum or plug such that the adapical termination of the internal mould is well rounded (figs $2 \mathrm{~B}, \mathrm{E}$ ). The oblique nature of the adapertural fracture of the internal mould has resulted in the loss of a quarter of a whorl of the upper whorl surface, relative to the lower whorl surface. It is unfortunately within this missing portion that the actual area of muscle attachment on the upper whorl surface was almost certainly located. The relationship of the present broken aperture to the true aperture is not known. In Bellerophon, the muscle attachment scars lie about half a whorl back from the apertural margin (Peel 1972, 1976, 1982).

\section{Muscle scars in Porcellia woodwardi}

A single muscle attachment scar is preserved on the lower whorl surface of the specimen from Longnor, immediately adjacent to the fractured adapertural margin of the internal mould (figs 2C, D, F). The scar lies on the basal surface of the whorl, next to its almost perpendicular junction with the umbilical wall. The muscle scar is shallowly crescentic with the concave side of the crescent lying on the adumbilical side. The scar extends over more than one eight of a revolution and its length, measured spirally around the whorl, is more than seven times its width (fig. 2D).

The muscle attachment scar lies at the adapical termination of a prominent spiral ridge which lies along the baso-umbilical shoulder. This ridge is deeply channeled along its convex margin, but finer grooves also occur along its crest (fig. 2D). The spiral ridge corresponds to a groove on the shell interior; the channel along its convex margin represents a thin flange protruding from the shell interior.

The surface of the muscle scar shows a number of fine striations. Striations are also visible on the umbilical wall in apical (fig. 2E) and basal (fig. $2 \mathrm{~F})$ views, but do not show any apparent association with a muscle attachment area.

The upper, apical, surface shows a well developed spiral ridge at the apico-umbilical shoulder (fig. 2B) which appears to be initiated at about the same growth stage as the similar ridge on the basal surface. Breakage of the internal mould prevents description of the muscle attachment scar which clearly lay at the apical termination of the spiral ridge.

It is evident that Porcellia woodwardi possessed two muscle scars and that these were located at approximately corresponding positions on the upper and basal whorl surfaces. It is not possible, however, to demonstrate that the two muscle scars were identical in size or shape. Neither can it be conclusively shown that the precise location of each scar relative to the apico-umbilical, or baso-umbilical shoulder, respectively, was the same. 


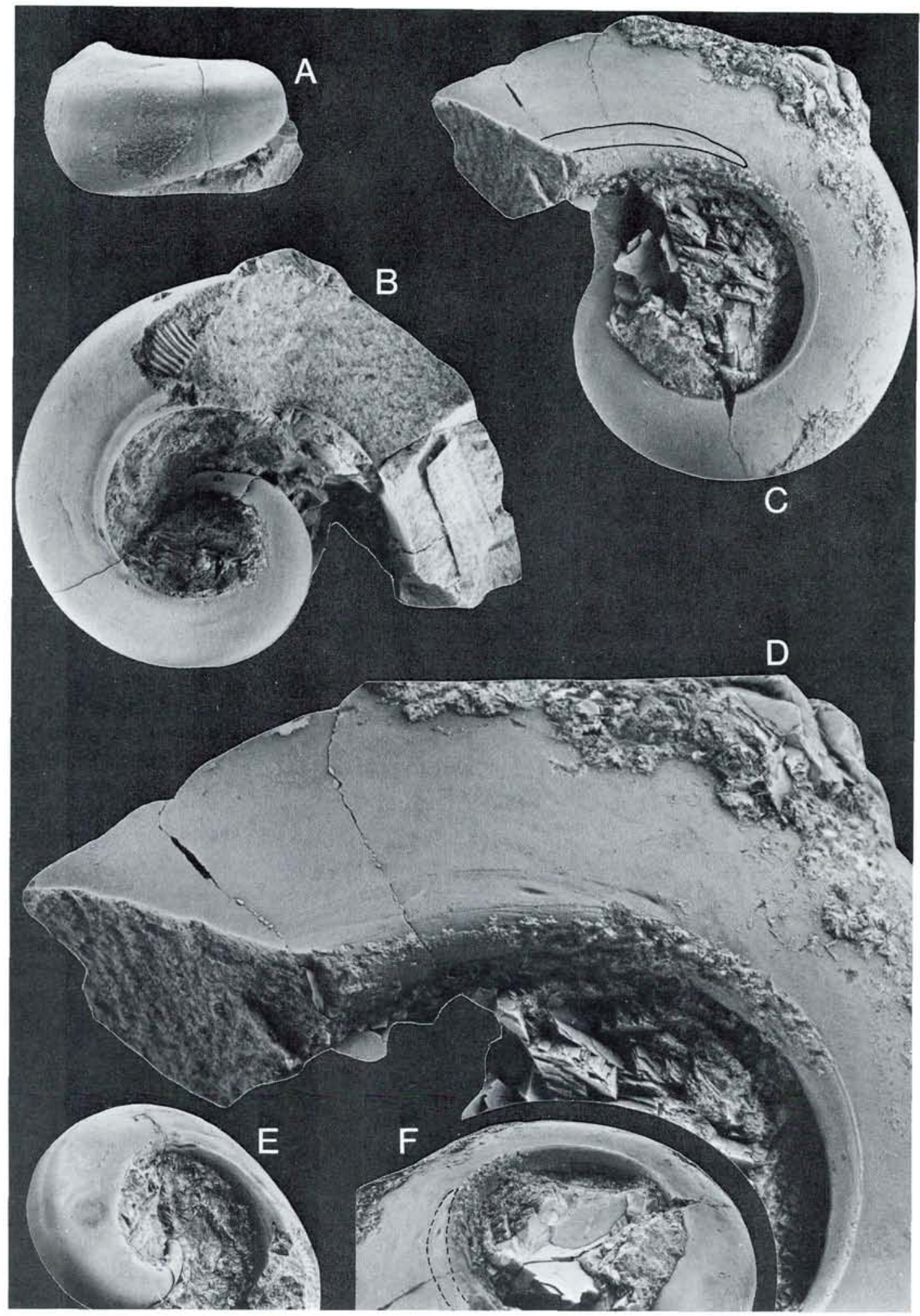




\section{Comparison with Bellerophon}

Muscle scars in specimens of Bellerophon of Carboniferous age have been described by Knight (1947) and Peel (1972, 1982). The spiral ridges and accompanying grooves seen in Porcellia woodwardi (figs $2 \mathrm{~B}, \mathrm{C}$ ) are similar to structures commonly occurring in bellerophontiform molluscs, e.g., Bellerophon itself, Salpingostoma Roemer 1876 and Megalomphala (Peel 1972, 1976, 1982). However, in a specimen of Bellerophon described by Peel (1972, text-fig. 1; 1976, fig. 1) from the Carboniferous of Northern Ireland, each spiral ridge appears to lie within the muscle attachment area, and not adapical to it, as in Porcellia woodwardi. Peel (1976) speculated that the length of the spiral ridge in Megalomphala taenia (Lindström 1884) from the Silurian of Gotland might be equated with the length of the muscle attachment scar. This is not the case in Porcellia woodwardi where the area of muscle attachment lies at the adapertural termination of each spiral ridge. The spiral ridges and the accompanying channels thus seem to represent the trace of the migrating muscles.

Peel (1982, text-fig. 2) restored muscle scars in Bellerophon recticostatus Portlock 1843 from the Carboniferous of Northern Ireland as V-shaped in form. One limb of the $\mathrm{V}$ lay along the umbilical shoulder, in similar fashion to the preserved muscle scars in Porcellia woodwardi, while the second limb lay on the umbilical wall parallel to the axis of coiling. The two limbs were joined adaperturally, i.e., the point of the $V$ lay towards the aperture. While a numbr of striations occur on the umbilical wall of Porcellia woodwardi (figs $2 \mathrm{E}, \mathrm{F}$ ), there is no substantial evidence that an area of muscle attachment lay on the umbilical wall, neither that each muscle scar had a shape other than the simple, shallow crescent visible on the base (fig. 2D).
Systematic position of Bellerophon

At first glance, the differences in detail between the muscle scars in Porcellia woodwardi, an uncontested gastropod, and Bellerophon are of sufficient magnitude to cast doubt on the supposed gastropod affinity of Bellerophon. It is clearly premature, however, to reject Bellerophon as a gastropod on this basis alone, although supporters of such a rejection can undoubtedly cite other supportive evidence (see review by Harper \& Rollins 1982). It is relevant to note that muscle scars of Bellerophon are also equally disimilar in shape to those of other bellerophontiform molluscs widely, if not universally, accepted as monoplacophorans, e.g., Sinuitopsis Perner 1903 (Rollins \& Batten 1968), Cyrtonella Hall 1879 (Rollins 1969), Sinuites Koken 1896 (Peel 1980; Runnegar 1981), Sylvestrosphaera Peel 1980 (Peel 1980), and Cyrtolites and its allies (Horny 1965).

On the basis of the restricted information currently available, it must be concluded that the form of individual muscle scars does not provide unequivocal evidence concerning the gastropod or monoplacophoran affinity of Bellerophon, since known muscle scars in that genus show equal degrees of disimilarity in terms of form to the muscle scars of an undoubted gastropod (Porcellia woodwardi) and to those of supposed (at least, prior to Harper \& Rollins 1982) monoplacophoran bellerophontiform molluscs of the Cyrtonella, Cyrtolites and Sinuites types. This conclusion echoes earlier expressed opinions concerning the significance of both the number of muscle scars and their pattern on the dorsal surface of bellerophontiform molluscs (Runnegar 1981; Harper \& Rollins 1982; Peel 1982).

Acknowledgement. Publication is approved by the Director, Grønlands Geologiske Undersøgelse.

Fig. 2. Porcellia woodwardi (Sowerby 1829), internal mould from the Lower Carboniferous of Longnor, Staffordshire, England, specimen number Geology E 2215 in the collections of Oxford University Museum. A, lateral view showing slight asymmetry of the whorl profile, $\times 1.5 ; \mathrm{B}$, upper surface showing the damaged final quarter of a whorl. Closure of the interior of the original shell by a septum or plug is indicated by the sudden, rounded termination of the internal mould. A prominent spiral ridge occurs at the apicoumbilical shoulder; it is channeled along its convex side and extends over about one quarte of a whorl back from the broken aperture, $\times 2$; C, basal view showing the spar-filled umbilicus. The prominent ridge of the baso-umbilical shoulder terminates adaperturally in a shallowly crescentic muscle scar (inked), $\times 2$; D, enlargement of $C$ to show details of the muscle scar, $\times 4 ; E$, oblique view of upper surface showing striations on apico-umbilical wall, $\times 1.5 ; \mathrm{F}$, oblique view of basal surface with muscle scar inked, showing striations on baso-umbilical wall, $\times 2$. 


\section{Dansk sammendrag}

I nærværende arbejde beskrives muskelaftryk hos Porcellia woodwardi (Gastropoda; Pleurotomariacea) fra Englands Karbon. Muskelaftrykkene er crescent-formet (fig. 2D) og ligger tat ved stenkærnernes apico-umbilical- og baso-umbilicalvægge. Muskelaftrykkene kan ikke nøje sammenlignes med muskelaftryk beskrevet hos bellerophontacer eller spiralsnoet monoplacophorer.

\section{References}

Batten, R. L. 1966: The Lower Carboniferous gastropod fauna of the Hotwells Limestone. Palaeont. Soc. Monogr., 109 pp.

Harper, J. H. \& Rollins, H. B. 1982: Recognition of Monoplacophora and Gastropoda in the fossil record: a functional morphological look at the bellerophont controversy. Proc. Third N. Am. Paleont. Conv. I, 227-232.

Horny, R. J. 1965: Cyrtolites Conrad, 1838 and its position among the Monoplacophora (Mollusca). Sb. nár. Mus. Praze 21, 57-70.

Jordan, R. 1968: Zur Anatomie mesozoischer Ammoniten nach den Strukturelementen der Gehäuse-Innenwand. Beih. geol. Jb. 77, 1-64.

Knight, J. B. 1947: Bellerophont muscle scars. J. Paleont. 21, 264-267.

Knight, J. B. 1952: Primitive fossil gastropods and their bearing on gastropod classification. Smithson. Misc. Collns 117, $13,56 \mathrm{pp}$.

Knight, J. B., Cox, L., R., Keen, A. M., Smith, A. G., Batten, R. L., Yochelson, E. L., Ludbrook, N. H., Robertson, R.,
Yonge, C. M. \& Moore, R. C. 1960: Treatise on Invertebrate Paleontology, I, Mollusca 1 (edit. R. C. Moore). Geol. Soc. Am. \& Univ. Kansas, Lawrence, 351 pp.

Koken, E. \& Perner, J. 1925: Die Gastropoden des Baltischen Untersilurs. Acad. Sci. Russie Mém., Classe physicomathématique $8,37,326 \mathrm{pp}$.

de Koninck, L. G. 1883: Faune du calcarie carbonifière de la Belgique, $3^{\mathrm{e}}$ partie, Gastéropodes (suite et fin). Mus. roy. Histoire nat. Belgique. Ann., Sér. paléont. 8, 240 pp.

Lemche, H. \& Wingstrand, K. G. 1959: The anatomy of Neopilina galatheae Lemche, 1957. Galathea Report 3, 9-71.

Peel, J. S. 1972: Observations on some Lower Palaeozoic tremanotiform Bellerophontacea (Gastropoda) from North America. Palaeontology 15, 412-422.

Peel, J. S. 1976: Musculature and systematic position of Megalomphala taenia (Bellerophontacea: Gastropoda) from the Silurian of Gotland. Bull. geol. Soc. Denmark 25, 49-55.

Peel, J. S. 1980: A new Silurian retractile monoplacophoran and the origin of the gastropods. Proc. Geol. Assoc. 91, 91-97.

Peel, J. S. 1982: Muscle scars in Bellerophon recticostatus (Mollusca) from the Carboniferous of Ireland. J. Paleont. 56, $1307-1310$.

Peel, J. S. 1985: Autecology of Silurian gastropods and monoplacophorans. Spec. Pap. Palaeontology 32, 165-182.

Rollins, H. B. 1969: The taxonomic position of Cyrtonella mitella (Hall) (Mollusca, Monoplacophora). J. Paleont. 43, 136-140.

Rollins, H. B. \& Batten, R. L. 1968: A sinus-bearing monoplacophoran and its role in the classification of primitive molluscs. Palaeontology 11, 32-140.

Runnegar, B. 1981: Muscle scars, shell form and torsion in Cambrian and Ordovician univalved molluscs. Lethaia 14, 311-322.

Wingstrand, K. G. 1985: On the anatomy and relationships of recent Monoplacophora. Galathea Report 16, 7-94. 